Bozan, M. (2019). The Role of Education: Capability Building or Transformation of Identity? Bartın University Journal of Faculty of Education, 8(2), 549-561.

Bartın University Journal of Faculty of Education, 8(2), 549-561

Bartın Üniversitesi Eğitim Fakültesi Dergisi, 8(2), 549-561

buefad.bartin.edu.tr

\title{
The Role of Education: Capability Building or Transformation of Identity?
}

\author{
Mahmut Bozan*
}

Article Info

\begin{tabular}{ll}
\hline \multicolumn{2}{l}{ DOI: $10.14686 /$ buefad.426770 } \\
\hline \multicolumn{3}{l}{ Article History: } \\
Received $\quad 24.05 .2018$ \\
Accepted $\quad 14.12 .2019$ \\
Published $\quad 30.06 .2019$
\end{tabular}

Keywords:

Education,

Democratic Education,

Values Education,

Ideological Education

Article Type: Review article

\begin{abstract}
Education is an instrument both to protect and bequeath the identity and values of a nation and to provide scientific and technical progress. The first function of education is cultural and local; its second function is international or global. Education preserves nations through the former while it builds civilizations through the unification of ideas provided by the later. In addition, education is the responsibility to prepare the most appropriate environment and ground, which improve child's ability and aptitude. This might be possible with educational policies which direct its central focus on students. Education is not a factory to grow up people whose body is native but spirit and values belongs to the West. Today, the most threatening element to education is the appropriation of technological advancements which are the common property of mankind for the West and, through it, the efforts for internalization and presentation of Western values as "universal values" by sanctifying them. In statist conception which defines education as "the development of 'desired' behaviours in children", the "desired" values have never become people's values. On the contrary, they became Western values presented in such packs as "universal, contemporary and modern". There is nobody who asks the opinion of society in this respect. The Western values are imposed to society by law. This situation threats our identity which is the constant value of education. This research aims at demonstrating how democracy indispensable for education as much as political system and providing a basis for an academic discussion.
\end{abstract}

\section{Eğitime Biçilen Rol: Yetenek Geliştirme Mi? Kimlik Dönüștürme Mi?}

\begin{tabular}{|c|c|}
\hline \multicolumn{2}{|c|}{ Makale Bilgisi } \\
\hline \multicolumn{2}{|c|}{ DOI: 10.14686/buefad.426770 } \\
\hline \multicolumn{2}{|c|}{ Makale Geçmişi: } \\
\hline Geliş & 24.05 .2018 \\
\hline Kabul & 14.12.2019 \\
\hline Yayın & 30.06 .2019 \\
\hline \multicolumn{2}{|c|}{$\begin{array}{l}\text { Anahtar Kelimeler: } \\
\text { Demokratik Eğitim, } \\
\text { Değerler Eğitimi } \\
\text { İdeolojik Eğitim }\end{array}$} \\
\hline
\end{tabular}

\section{$\ddot{O} z$}

Eğitim ve öğretim, bir milletin hem kimlik ve değerlerini koruma ve tevarüs etme, hem de bilim ve teknikte ilerlemesini sağlama aracıdır. Eğitimin birinci fonksiyonu kültürel ve yerel, ikinci fonksiyonu ise beynelmilel ve evrenseldir. Eğitim birincisiyle milletleri ibka ederken, ikincisinin sağladığı telâhuk-u efkâr ile medeniyetleri inşa eder. Diğer yandan eğitim, çocuğun kabiliyet ve istidatlarını geliştirecek en uygun ortam ve zemini hazırlama sorumluluğudur. $\mathrm{Bu}$ ise talebeyi merkeze alan eğitim politikalarıyla mümkün olabilir. Eğitim; bir dönem yapıldığı gibi cesedi yerli, ruhu ve değerleri Batılı insan yetiştirme fabrikası değildir ve olmamalıdır. Günümüzde eğitimi mecrasından çıkaran ve bir propaganda aracı haline getiren unsurların başında, insanlığın ortak malı olan teknolojik gelişmelerin Batı'ya mal edilmesi, bunun üzerinden Batılı değerlerin kutsanarak "evrensel değer" olarak takdim edilmesi ve içselleştirilmesi gayretleri gelmektedir. Eğitimi, "çocukta istendik davranışlar geliştirme" olarak tanımlayan anlayışta "istendik" davranışlar maalesef halkın değerleri olamamıştır. Bilakis "evrensel, çağdaş ve modern" gibi ambalajlar içinde sunulan Batılı değerler olmuştur. Toplumun bu husustaki görüşlerini soran da yoktur. Batılı değerler millete kanunlarla dayatılmaktadır. Bu durum eğitimin sabit değeri olması gereken kimliğimizi tehdit etmektedir. Bu çalışma, demokrasinin siyasi sistem kadar, eğitim için de vazgeçilmez olduğunu ortaya koymayı ve en azından disiplinler arası bir tartışma için zemin oluşturmayı amaçlamaktadır.

\footnotetext{
${ }^{a}$ Prof. Dr., Bartın University Faculty of Economics and Administrative Sciences, Department of Political Science and Public Administration. Bartın, Turkey, https://orcid.org/0000-0002-5396-7021.
} 


\section{Introduction}

Some people define education as a process which helps the development of personality and is based on the individual, prepares them for adulthood and equips them with the necessary knowledge, skills and behaviours (Tezcan, 1985, p.4) while others define it as "a process during which desired changes are made in an individual's behaviours (Ertürk, 1972, p. 12). The direction of the changes in the behaviours and what is meant with desired behaviours are open to interpretation. However, it is emphasized that there are teaching and education dimensions (Aydin, 2009, p. 33); and teaching develops scientific capacity while education helps to be a good person.

One of the most distinguishing feature among human and animals is that while animals are born with the knowledge to survive, human are born without this knowledge. As Kant (1900, p.1-2) indicates while a baby animal is sent to the world "trained", human are sent to the world to be trained. While doing some activities in certain areas in a perfect way, animals look like they are programmed robots. But they do not go beyond the program set for them. However, human beings are born with a need for knowledge and as unknowing the rules of life but then, contrary to the restrictions of animals, human beings have an unlimited learning capacity. The requirement of human beings to develop through learning and education makes education very important.

The value of education for human beings makes education a topic of discussion. In other words, it is necessary to properly answer such issues as what the purpose of education is, who will deliver education, when and how they will deliver it. On the other hand, the main issues such as whether education will be used to develop the skills of human beings or as a tool to transform personality based on the wills of others are still being discussed. Due to this critical and strategic importance of education, as in all developed countries, education has always been a primary issue of state and government policies in Turkey.

\section{Education as a Tool to Develop Skills}

Human beings have different skills and competences by nature and since there are no boundaries in feelings, there are no boundaries in the development and advancement of these feelings. However, education is a must for the development of human skills. Otherwise, skills cannot develop and one cannot reach his/her full capacity. This indispensability of education attracts attention on education and educational institutions. Beyond doubt, in addition to its formal and systematic dimension, education has different types like education in the family, everyday practices, non-formal education, courses, seminar and self-directed learning (autodidactic). The most effective one among all these kinds of education is the one that is delivered by teachers in an educational institution and the most distinctive one of this kind of education is compulsory education or primary education.

Because many factors such as the school culture, the education policies in the school, curriculum, the character of the teachers implementing this curriculum in the school as well as their mind-set and ethical values will be effective in shaping the character of the child.

If education will be used as a tool to develop the skills of the people, the first condition is that it should be student-centred. Student-centred approach aims to educate a child based on his/her existing skills, not according to what adults want (Gür, 2006, p.34). This will be similar to providing the necessary conditions for a chick coming to life with its own features to turn into a developed peacock or a tree seed to sprout into a big pine tree.

The next condition following a student-centred education is to offer a culture and civilization environment in which children will inherit the values of family and society, in other words, to educate them with their own values. This indicates the ethical dimension of education. Both teachers and schools and relevant Ministry should take the necessary measures for this kind of an education and curriculum should be structured accordingly.

\section{Does Educational System Take Individual Differences into Consideration?}

Ottoman Empire's educational system took individual differences into consideration (Baltac1, 1996, p.467). However, with the spread of Western-type schools in Turkey after the industrial revolution when there was mass education in parallel to mass production, individual differences were ignored. All children in a classroom started to be educated as they were all the same. This was a big educational mistake because it might not be a problem to produce telephones with mass production and even it is necessary to standardize. However, if individual differences are not taken into account and individuals are not provided with an education to develop their individual skills, there will always be a risk to waste some skills. 
Gardner's "multiple intelligence theory" suggests that human beings have different skills and a standardized education ignoring these differences will not improve but destroy these skills. Unwillingness among students who are forced to an education out of their own interests, drop-outs and even violence towards students by some teachers are just a few examples to the results of mass education.

When education is shaped in a student-centred way in which each student is taught the same topics in different ways, it will help to create a happy environment in which each student will find their own way, feel better and even will be more useful to the society. In an environment in which there is a standard competence, and particularly one intelligence group is prioritized, it will be inevitable that some students will feel insufficient and thus, will be left out of the system. It is possible that there will be lots of geniuses in this group (Altan, 1999, p. 112).

In today's world in which even product diversity and variety is offered in production based on the demands of the customers, it is quiet alarming that education is mass and monotype. Although schools have psychological counselling and guidance units for students, the result does not change because the system is built as mass education. There is a fixed curriculum in school and all students are expected to take it in equal time periods. The success rates in elective courses and guidance to a field are low. The problems in choosing a field of study continues until higher education.

To sum up, it can be said that education system is not flexible to consider individual differences. School facilities, teacher training institutions and curriculum do not comply. Majority of the students overwhelmed with this education which does not consider individual differences, some of their skills are wasted and they are directed towards fields they are not interested which, then, causes to both failure and wasting of human capital roughly.

\section{Education as a Tool to Transform Identity}

If education is not built in a student-centred or people-oriented manner, instead of using it as a tool to develop skills, it could be used as an identity transforming tool. In such cases, such trends as educating people based on Western values like the ideal to educate future generations with a modern and contemporary understanding, which does not have a reflection on people and does not have a sociological background, emerge. In addition, sometimes, it could be used as a tool for brainwashing or propaganda by some ideologies.

Gökalp (1994, p. 25), who indicates that culture is national and civilization is international, defines culture as "the harmonious whole of the religious, ethical, legal, mental, linguistic, economic and scientific life of a single nation."

Açıkgenç (2009: 79), on the other hand, states that in Turkey, there is no social philosophy that reflects our educational understanding and that all educational theories developed until present day are of Western origin. Şimşek (2000: 31) states that the most rooted criticism made towards school since the beginning of nation-states is that it is a tool under the control of dominant powers or ruling political parties.

In the Education budget negotiations in 1917, Hilmi Bey, the Deputy of Basra, mentions three trends in the country. He says that one of these trends is the admiration for Western civilization and those who are in this group believe that development can be achieved on condition that we "distance ourselves from religion and traditions". The second group claims "Western civilization does not comply with Islam and therefore, it is necessary to stay away from West" whilst the third group claims that "Islam is not an obstacle before development, and indeed it orders development and that only science and technique of the West should be adopted but our national and intangible values should be preserved" (Ergin, 1977, p. 1363).

In discussions made on the topic, the reason behind these three opposite trends was considered to be due to the controversy between madrasah, school and dervish lodges; and Pious Foundations lacked rehabilitation so it was demanded that Pious Foundation should be given authority in financial issues whilst Department of Religious Affairs should be authorized in scientific and educational issues (Ergin, 1977, p. 1347).

In this case, it is important to carefully analyse for whom, for which purposes, by whom and through which curriculum education is offered and to review its level of democracy. Education is a human right, and determining how the right to education will be used is a democratic right. No one can see the right and authority to determine the curriculum and content by leaving society, parents and even students aside. No group or segment holding public power can/should see themselves as the decision-making authority to make final decisions on education. So who will be the authority to decide on how the right to education shall be used and how the curriculum shall be determined? These questions turn the issue of democratizing education into an obligation. 


\section{Democratic Education}

Education is one of the essential democratic rights of today. Therefore, in all societies from the most developed to the least, primary education has become compulsory. However, that is not enough but indeed it is just the beginning. Whether the education is student-centred or ideological aiming to make individuals tin soldiers is as important as the right to education. Because the most essential target group of ideologies is the children at school age. Since ideologies desire everyone to think like them and even to be completely same with themselves, they want to use education as a tool to reach that aim. The aim of democratic education, on the other hand, is to develop the skills of the individual and to teach them the ways to search for reality using free thought, research, criticism and scientific methods. While ideologies present themselves as the target of science to be reached, democratic education offers individuals new horizons freeing them from the narrow patterns and dead ends of ideologies. As Bursalıoğlu (1991, p. 192) states: "If an administration in a country tries to organize curriculum, books, classrooms, principals and teachers, it shows that democracy is that country exists only formally."

It is reminded that the overall objectives of Turkish National Education do not comply with the criteria set for the development of individual, society and economy in Lisbon Summit; whilst the aims and objectives set for education do not comply with the Copenhagen criteria and that these compliances should be ensured considering the relations developed through Bologna Declaration (Toku, 2009, p. 243-245).

The method, tools and institutions of democratic education are as important as the concept itself. So what is meant by democratic education? We can find an answer to this question by analysing the two dimensions of education. The first one is to teach children the fundamental sciences which are valid the same way all around the world and include physics, chemistry, biology, mathematics, geography and such. The second one is more local, cultural, national and intangible values. Nations transfer their genetic codes to future generations through this and thus become everlasting.

Natural sciences dimension of education can never be restricted to a continent, region or nation. All humanity has a contribution to it. Person who invented the wheel has a contribution like the one who found the idea of minimizing friction in a satellite sent to the space and this contribution cannot be underestimated and ignored. Knowledge is the common property of humanity and it should not be made an instrument to a Western ideology (Bolay, 1996, p. 428). Western countries cannot claim that the accumulated knowledge that has been created with shared wisdom of humanity until present day belongs to them. Such a claim is unrealistic, it means ignoring other nations and civilization and is also civilization plagiarism.

Local, cultural values and colours, the second dimension of education, are the existential and survival guarantee of the nations. Cultural values, traditions and customs of developed nations are not universal as the first dimension of education but local and restricted to that society. Justifying their development, they cannot be taken as example, imitated and presented as upper value with a claim that they are "modern". What is meant by democratizing education is being committed to the values of the society, being sensitive to the demands of the society, respecting the skills of individuals, teaching universal science and technology at international standards and not allowing the use education as a propaganda tool.

Therefore, the system, including the educational policies, educational institutions, teacher education and curriculum should be restructured in a holistic manner based on the demands of the society. What is meant with holistic here is ensuring the commitment of social contract, in other words the society, in all processes including school management, Ministry of Education, educational legislation and Constitution.

\section{Values Education}

Values can be defined as mental facts in affective domain and they affect and shape our thoughts and actions (Demircioğlu \& Tokdemir, 2008, p. 71). Values that societies form in centuries; transform into tradition and custom and hand down for future generations are their survival guarantees and it is necessary to sustain, share and teach them to future generations. The most significant feature of values is that they are internalized and adopted by the majority of the society (Bolay, 1996, p. 425, Tarhan, 2012, p. 20). However, there is no consensus on what is meant with the concept of value. It is known that since the Tanzimat Reform Era, what is meant by contemporary civilization, modernizing and becoming contemporary is Western values and that the same values are referred to with the concept of "universal values". However, considering the fact that Western values were developed against the pressures of the church, it can be said that these values are compatible with our values. Also it is not possible 
to talk about a Westernization demand from the society. With the decline of Ottoman Empire and the strengthening of Europe, such tendencies as acquiring Western values and institutions occurred among intelligentsia and discussions about whether Westernization is a technical adaptation or passing from one civilization area to another, in other words, leaving the Eastern civilization and accepting Western civilization (Tunaya, 2004, p. 18) have started to be discussed.

There are also European people who were involved in this discussion. Against the suggestions of Austrian Prime Minister Prince Metternich, who indicated that "European civilization is different and completely dissimilar to Eastern traditions and customs and therefore, it would be a total mistake to adopt Western values" (Meriç, 1997, p. 165), there were others from inside who had counterclaims such as "We should immediately change from Eastern civilization area to the Western civilization, West is a mindset, a soul, a mind. If it is not taken that way, it would be just an unconscious imitation. West is modern civilization. East is dark" (Tunaya, 2004, p. 130). Sharing a similar opinion and even going further, Ağaoğlu (1972, p. 11-13) insists that Western civilization is an indivisible integrity and therefore, in order to exist, we should adopt it completely.

Values education is not only a popular issue in our country but also in the world and particularly in Europe. It would not be exaggeration to say that values education in our country become a current issue as a reflection of the discussions in Western countries. Regretfully, our country has not freed itself from being effected and follower.

It would be right to mention about an anonymous educational advice which sums up the issue. A principal's message to the teachers of the school, who witnessed the concentration camps in Hitler's Germany draws attention to the dangers of an education without ethical values. "I am a survivor of a concentration camp. My eyes saw what no man should witness: Gas chambers built by learned engineers, children poisoned by educated physicians, infants killed by trained nurses. Women and babies shot and buried by high school and college graduates. So, I am suspicious of education. My request is: Help your students become human. Your efforts should never produce learned monsters, skilled psychopaths, educated Eichmans. Reading, writing, and arithmetic are important only if they serve to make our children more humane."

What brings the issue of values education into agenda in Western countries is the materialistic understanding in the philosophical values of Western civilization and their ignorance of sentimental values. Because Western civilization is not based on right but strength. It puts benefit to the target. It sees life as a war in which only strong have the right to live and weak are eliminated through this natural selection. As this kind of a mentality also nurtures the feeling that the survivors are the master race, it turns into enslaving, assimilating other societies or deporting them, all of which destroys human dignity and honour.

As satisfying personal desires forms the basis, it popularizes the type of human who is hedonist and selfish. This kind of a mind-set that becomes rooted in the West takes the society to disintegration, breaks down the family and isolates people by pushing them towards alcoholism and addiction. This is the impetus that forms the need for "values education" in the West.

In Turkey, on the other hand, as West is seen as the source of reference, values education is honoured like a fashion, so to say. Now we see an invasion of values education like the "Total Quality Management" outbreak which was once popular and left formalist residues. Sometimes the solid principals of values building civilizations are ignored and restricted to sometimes humanist perspectives, sometimes environmental sensitivities, ideological definitions and sometimes one-day ethical concerns. Modernism purified from sentimental values and shined by such concepts as modern and universal ruin punishment and reward system in the brain. It brings hedonism to the first place and as a result, egoism occurs. Defined as Californian syndrome, egoism ends with hedonism, egocentrism, thinking about one's own good and comfort, isolation and finally, unhappiness and depression (Tarhan, 2010, p. 244).

Bolay (1996, p. 426) indicates that with the impact of positivism since the end of the last century our education has been in metaphysics phobia and depends upon one-sided educational understanding which ignores and denies the spiritual side of the human being.

Therefore, it is necessary to mention that there is a need for consensus on what is meant by values education. Otherwise, we will encounter different definitions of values education. Otherwise, contrary to the saying: "everyone has the same purpose but says it in a different way" we will encounter different definitions of values education as in "everyone has similar statements but have different purposes". Without ignoring the difficulties in defining concepts, it is possible to say the following. While defining values, first national identity and later, 
international commitments could be considered. Governments can produce values over the commons of belief and culture basins and call for civilization to humanity. On a global scale, agreement on values will be more difficult, and therefore it is necessary to narrow down the negative area, in other words, to take measures to prevent race and belief hostility and not to include attitudes that will cause to hostility in education.

Finally, it will be useful to look into how our country regulated values education in law and other legal legislation. Equality before the law is for executive, legislation and judiciary. If such a generalization is avoided, the rule loses its impact and concreteness. Moreover, "binding force of the constitution" does not include a distinction among executive, legislative and judiciary bodies. "Law cannot be made for or against a particular person, group or class." The relation between the general structure of law (impersonal) and the concept of "equality" can be examined in this respect (Erdem, 1981, p. 486-497).

The second article of the Basic Law of National Education no. 1739, the purpose of National Education is defined as given: "to raise individuals who are committed to Atatürk's reforms and principles, his concept of nationalism as defined in the Constitution; who adopt, protect and improve the national, moral, human, spiritual and cultural values of the Turkish nation; who love and always elevate their families, homeland and nation; who are aware of their duties and responsibilities towards the Turkish Republic, which is a democratic, secular and social state ruled by law based on human rights and the basic principles defined in the beginning of the Constitution and behave accordingly." (RG. 1973: no, 14574).

When the purposes of formal and non-formal pre-school, primary and secondary education are examined, it is seen that the same "principles and general objectives" are repeated at all levels. Similarly, in the 4th article of the Law on Higher Education no.2547, the aim of higher education is defined as "To educate students so that they will be loyal to Ataturk nationalism and to Ataturk's reforms and principles". In the 5th article which sets how higher education is organized, planned and programmed, it is indicated that "it will be ensured that students develop a sense of duty in line with Ataturk's reforms and principles, loyal to Ataturk nationalism” (RG. 1981: no, 17506).

\section{Conclusion}

For human beings, whose emotions and skills cannot be limited, education is the most indispensable tool and a basic human right to self-realization, in other words to reach the maximum potential. Human beings can climb up the steps of development through learning science. However, discussions on how to determine the content of education, whether it will be used to develop an individual's skills or to shape people towards a certain purpose, in other words, to format them still continue.

Of course it is desired that education should be a tool for developing skills, values are determined according to the demands from the society, the universal part of science is included in the curriculum in a competitive manner and beliefs, traditions, customs are preserved. However, it is unacceptable that education is used as a tool to transform identity in anti-democratic ways, dictating attitudes, by-passing the society and as a tool for some ideologies.

Looking for values for education without democratizing it is open to routing the same way raising a building without making a land survey. Prioritizing the democratization of education will not only remove the ambiguities in seeking a better future in education but also will make the roadmap of values or values education which will ensoul education. 


\section{Eğitime Biçilen Rol: Yetenek Geliştirme Mi? Kimlik Dönüştürme Mi?}

\section{Giriş}

Eğitimi kişiliğin gelişmesine yardım eden ve onu esas alan, onu yetişkinliğe hazırlayan, gerekli bilgi, beceri ve davranışlar elde etmesine yarayan bir süreç olarak tanımlayanlar olduğu gibi (Tezcan, 1985: 4), "Bireyin davranışlarında istendik değişme meydana getirme süreci” olarak tarif edenler de vardır (Ertürk, 1972: 12). Bireyin davranışlarındaki değişikliğin ne yönde olacağı, istendik davranışlardan ne kastedildiği hususu da yoruma açık olmakla birlikte eğitimin bir tâlim, bir de terbiye yanı olduğu (Aydın, 2009: 33), tâlimle bilimsel kapasite geliştirilirken terbiye ile de bireyin iyi insan olmasının sağlanacağı üzerinde durulmaktadır.

İnsanla hayvan arasındaki en ayırt edici özelliklerden birisi, hayvanların hayatlarını idame ettirecek kadar bir bilgi donanımıyla dünyaya gelmelerine mukabil, insanların bu bilgiden mahrum olarak doğmalarıdır. Kant'ın (1900: 1-2) da belirttiği gibi, bir hayvan yavrusu adeta dünyaya "eğitilerek" gönderilirken, insan yavrusu eğitilmek için gönderilmektedir. Hayvanlar belirli alanlarda belirli faaliyetleri mükemmel bir şekilde yaparken adeta programlanmış bir robot intibaı verirler. Fakat kendileri için belirlenen programların dışına çıkamazlar. Oysa insan dünyaya bilgiye muhtaç ve hayat kanunlarına câhil olarak gelir fakat hayvanın sınırlılığının aksine, sınırsız bir öğrenme kapasitesine sahiptir. İşte insanın öğrenme ve eğitimle gelişme mecburiyeti eğitimi çok önemli hale getirmektedir.

Eğitimin insan için taşıdığı değer, eğitimin kendisini de tartışmaya açmaktadır. Yani eğitimin amacının ne olduğu, kim veya kimler tarafından verileceği, hangi zaman diliminde ve nasıl verileceği gibi hususların doğru şekilde cevaplanması gerekmektedir. Diğer yandan eğitimin insanın sahip olduğu yetenekleri geliştirmek için mi yoksa başka bir iradenin istekleri doğrultusunda bir kimlik dönüştürme aracı olarak mı kullanılacağı gibi hususlar da aynı şekilde temel tartışma konularını teşkil etmektedir. Eğitimin bu kritik ve stratejik önemi sebebiyle tüm gelişmiş ülkelerde olduğu gibi ülkemizde de eğitim devlet ve hükümet politikalarının daima öncelikli meselelerinden biri olmuştur.

\section{Bir Yetenek Geliştirme Aracı Olarak Eğitim}

İnsan mahiyet itibariyle pek çok farklı yetenek ve kabiliyetlere sahip olup, yaradılış itibariyle duygularına bir sınır konulmadığı için inkişaf ve terakkisinde sınır yoktur. Fakat insanın yeteneklerinin gelişimi için eğitim ve öğretim şarttır. Aksi takdirde yetenekleri inkişaf edemez, kapasitesindeki en üstün noktaya gelemez veya noksan kalabilir. Eğitim ve öğretimin bu vazgeçilmezliği, dikkatleri eğitime ve eğitim müesseselerine çekmektedir. Şüphesiz eğitim ve öğretimin bir örgün ve sistematik boyutu olduğu gibi aile içi eğitim başta olmak üzere, günlük hayat pratikleri, yaygın eğitim, kurs, seminer ve kendi kendine öğrenme (otodidakt) gibi çeşitliliği barındıran yanları da vardır. Ancak bunlar içinde şüphesiz en etkili olanı bir eğitim kurumu içinde öğretmenler tarafindan verilen eğitimdir ve bunun da en belirleyici olanı mecburi eğitim veya temel eğitimdir.

Çünkü okul kültürü, okuldaki eğitim ve öğretim politikaları, eğitim müfredatı, bu müfredatı uygulayan öğretmenlerin düşünce yapısı, karakteri, ahlâk ve değer yargıları gibi pek çok unsur çocuğun kişiliğinin şekillenmesinde etkili olacaktır.

Eğer eğitim insanların sahip oldukları yeteneklerin geliştirilmesinde bir araç olarak kullanılacaksa bunun birinci şartı eğitimin öğrenci merkezli olmasıdır. Öğrenci-merkezli yaklaşım, çocuğu yetişkinlerin isteğine göre değil, çocuğun sahip olduğu yeteneklerine göre eğitmeyi amaçlar (Gür, 2006: 34). Bunun mânası eğitim adeta bir yumurtadaki civcivin kendi özellikleri ile canlanması veya bir çekirdekteki ağacın kendine has özellikleri ile filizlenerek mesela tekâmül etmiş bir tavus kuşu veya boyutlarının en üst noktasına erişmiş bir çam ağacı olmaları için gerekli şartları sağlamakla eşanlamlı olacaktır.

Öğrenci merkezli eğitimden sonraki şart ise çocuğa aile ve toplum değerlerini tevarüs edecek bir kültür ve medeniyet ortamı sağlanması, yani kendi değerleri ile yetiştirilmesidir. Bu da eğitimin ahlâki boyutunu teşkil eder. Böyle bir eğitim için hem öğretmenler, hem okul ve hem de ilgili Bakanlık gerekli tedbirleri almalı, müfredat ona göre yapilanmalıdır.

\section{Eğitim Sistemi Ferdi Farklılıkları Dikkate Alıyor mu?}

Osmanlı Devletinde öğrencilerin ferdi farklılıklarını dikkate alan bir eğitim sistemi vardı (Baltacı, 1996: 467). Bu sebeple Osmanlı medreselerinde yüzlerce öğrenciyi içinde toplayan amfilere ve dersliklere rastlamak mümkün değildir. Oysa sanayi devrimi sonrası kurulan fabrikalarda seri üretime paralel olarak seri eğitim yapılan Batı tipi okulların Türkiye'de de yaygınlaşması sonucu öğrencilerin ferdi farklılıkları göz ardı edilmeye başlandı. Bir sınıfı 
dolduran çocukların hepsi birbirinin aynısıymış gibi eğitim verilmeye başlandı. Bu büyük bir eğitim hatasıydı. Zira seri üretimle birbirinin aynısı olan telefonlar üretmekte bir mahzur olmayabilir, hatta standartlaştırma gereklidir de. Ancak insanların ferdi farklılıkları dikkate alınarak her şahsın kendi yeteneklerini inkişaf ettirecek bir eğitim verilmediği takdirde, bazı kabiliyetlerin öldürülmesi gibi bir tehlike her zaman mevcut olacaktır.

Gardner tarafindan ortaya atılan "çoklu zekâ teorisi" insanların farklı kabiliyetlere sahip olduğunu, bunları dikkate almayan tek tip eğitimin bu kabiliyetleri geliştirmek değil tahrip edebileceğini ortaya koymuştur. İlgi alanlarının dışında eğitime zorlanan öğrencilerde eğitime karșı isteksizlik olması, eğitimin terki ve hatta bazı eğitimciler tarafından öğrencilere şiddet uygulanması seri eğitimin sonuçlarından sadece küçük bir kısmıdır.

Her çocuğun yine aynı konuları ancak farklı yollarla öğrenecekleri birey merkezli bir eğitim sürdürüldüğünde, her öğrencinin kendi çizgisini bulacağı, kendini daha iyi hissedeceği ve belki de topluma daha faydalı birer birey olabilecekleri mutlu bir ortamın oluşmasına yardım edilecektir. Sadece standart bir yeterliliğin bulunduğu, özellikle de sadece bir grup zekânın ön plânda tutulduğu bir ortamda, pek çok öğrencinin kendini yetersiz hissedeceği ve dolayısıyla sistemin dı̧ında kalacağı kaçınılmaz olacaktır. Muhtemeldir ki, bu grubun içinde birçok dâhi de bulunacaktır (Altan, 1999: 112).

Günümüzde üretim alanında bile müşteri taleplerine göre ürün çeşitliliği ve farklılaşması yoluna gidilerken eğitimin ısrarla seri olarak ve tek tip yapılması endişe vericidir. Her ne kadar okullarda öğrenciler için psikolojik danışma ve rehberlik birimleri olsa da sonuç değişmemektedir. Çünkü sistem temelde seri eğitim olarak kurgulanmıştır. Okulda sabit bir müfredat bulunmakta, bunu her öğrencinin eşit zaman dilimleri içinde alması istenilmektedir. Bu durumu bir kedi, kartal ve kaza birlikte uçma, kaçma ve yüzme eğitimi verme ve herkesten aynı başarıyı bekleme metaforu ile açıklayabiliriz. Her seferinde en az üçte birlik bir kesimin başarısızlık ve intibak meseleleri yüzünden psikolojik desteğe ihtiyacı olacaktır. Seçmeli ders ve alana yönlendirmede başarı oranları da düşüktür. Yükseköğretime gelinceye kadar alan seçimindeki sıkıntılar devam etmektedir.

Sonuç olarak denilebilir ki eğitim sistemi ferdi farklılıkları dikkate alacak esneklikte değildir. Okul yapıları da, öğretmen yetiştiren kurumlar da, müfredat da buna uygun değildir. Öğrencilerin büyük çoğunluğu ferdi farklılıkları nazara almayan eğitim çarklarının arasında ezilmekte, belki de bir kısım yetenekleri köreltilmekte, ilgisiz alanlara zorla yönlendirilmekte ve bu da hem başarısızlığı, hem de beşeri sermayenin hoyratça israfını netice vermektedir.

\section{Bir Kimlik Dönüștürme Aracı Olarak Eğitim}

Eğitimin öğrenci merkezli veya insan odaklı yapılanmadığı durumlarda yetenek geliştirici özelliğinden ziyade kimlik dönüştürme aracı olarak kullanılması gibi bir tehlike söz konusu olabilmektedir. Bu durumda bazen yeni nesilleri modern ve çağdaş bir anlayışla yetiştirme ideali gibi halkta mâkes bulmayan ve sosyolojik tabanı olmayan ve "evrensel" olduğu iddia edilen bir takım Batılı değerlere göre yetiştirme eğilimleri baş gösterdiği gibi bazen de ideolojilerin beyin yıkama veya propaganda aracı olarak da kullanılabilmektedir.

Kültürün millî, medeniyetin milletler arası olduğunu ifade eden Gökalp (1994, 25), kültürü; "yalnız bir milletin dinî, ahlâkî, hukukî, aklî, estetik, lisanî, iktisâdî ve fennî hayatlarının âhenkli bir bütünü" olarak tarif eder.

Açıkgenç (2009: 79) ise Türkiye'de bizim eğitim anlayışımızı yansıtan bir toplum felsefesinin olmadı̆̆ını, günümüze kadar geliştirilen bütün eğitim kuramlarının Batı menşeli olduğunu ifade eder. Şimşek (2000: 31), ulusdevlet oluşumunun başından beri okula yöneltilen en köklü eleştiriyi egemen güçlerin ya da siyasi iktidarların emrinde bir araç olmasında bulur.

1917 yılı Maarif bütçesinin müzakerelerinde Basra Mebusu Hilmi Bey memlekette üç cereyandan bahsetmektedir. Bunlardan birisinin Garb medeniyetine meftunluk olduğunu, bu grupta olanların terakkiyi "dinden ve an'anat-1 milliyeden tebaûd (uzaklaşma) etme" şartına bağladıklarını, ikinci grubun "Garb medeniyetinin İslam'la kabili te'lif olamayacağını, bu sebeple Garbdan uzaklaşmak gerektiğini”" savundukları, üçüncü grubun ise "İslâmiyet'in mani-i terakki değil, âmir-i terakki olduğunu, Garbın sadece bilim ve tekniğinin alınması, ancak kendi mânevî ve milli değerlerimizin korunması gerektiğị” görüşünde olduklarını belirtir (Ergin, 1977: 1363).

Yapılan tartışmalarda bu birbirine zıt üç cereyanın sebebi medrese, mektep ve tekke ihtilafına bağlanmış ve ıslahı için de Evkaf Nezareti'nin kifayet etmediği, mâli hususlarda Evkaf'ın ilmî ve terbiyevî hususlarda Meşihat'ın yetkili kılınması istenilmiştir (Ergin, 1977: 1347). 
Bu durumda eğitimin kim için, ne amaçla, kimler tarafından ve nasıl bir müfredat içeriği ile verildiğinin dikkatlice analiz edilmesi ve demokratiklik düzeyinin gözden geçirilmesi önem arz etmektedir. Eğitim bir insan hakkı olduğu kadar eğitim hakkının nasıl kullanılacağının belirlenmesi de bir o kadar demokratik haktır. Hiç kimse toplumu, ebeveyni ve hatta öğrencileri kenarda tutarak eğitim müfredatını ve içeriğini belirleme hak ve yetkisini kendinde göremez. Kamu gücünü elinde tutan hiçbir kesim veya grup kendini eğitimle ilgili nihai karar verme merciî olarak göremez ve görmemelidir. O halde eğitim hakkının nasıl kullanılacağı ve eğitim müfredatının nasıl belirleneceği hususunda kim yetkili kılınacak ve kararı kim verecektir? Bu sorular eğitimin demokratikleştirilmesi meselesini bir mecburiyete dönüştürmektedir.

\section{Demokratik Ĕgitim}

Eğitim, günümüzün vazgeçilmez demokratik haklarından birini teşkil etmektedir. Bu sebeple en gelişmiş toplumlardan en geri kalmışlarına kadar hepsinde temel eğitim mecburi hale getirilmiştir. Ancak iş bununla bitmemekte, belki de yeni başlamaktadır. Zira verilen eğitimin birey odaklı mı, yoksa bireyi kurşun asker yapmayı amaçlayan ideolojik odaklı mı olduğu, eğitim hakkı kadar önem taşımaktadır. Zira ideolojilerin en büyük hedef kitlesini eğitim çağındaki çocuklar teşkil etmektedir. İdeolojiler fikir hürriyetinden ziyade herkesin kendileri gibi düşünmesini, hatta kendileriyle aynileşmesini istedikleri için eğitimi bunun aracı olarak kullanmak istemektedirler. Demokratik eğitimin amacı ise bireyin yeteneklerini inkişaf ettirmek, hür düşünce, araştırma, eleştirme ve bilimsel metotları kullanarak gerçeği aramanın yollarını öğretmektir. İdeolojiler kendilerini bilimin varacağı hedef gibi takdim ederken, demokratik eğitim ideolojilerin dar kalıplarından ve çıkmaz sokaklarından azade olarak bireye sürekli yeni ufuklar sunar. Bursalığlu'nun $(1991 ; 192)$ deyimiyle "Eğer bir ülkede yönetim programlara, kitaplara, sınıflara, yönetici ve öğretmen davranışlarına kadar inerek düzenleme çabaları gösteriyorsa o memlekette demokrasi biçimsel olarak vardır."

Türk Milli Eğitiminin genel amaçlarının Lizbon Zirvesinde bireyin, toplumun ve ekonominin gelişimi için belirlenen kıstaslara uymadığı; eğitim için belirlenen amaç ve hedeflerinin de Kopenhag kriterlerine uymadığı, Bologna Deklarasyonu ile geliştirilen ilişkiler dikkate alınarak bu uyumların sağlanması gerektiği hatırlatılmaktadır (Toku, 2009: 243-245).

Demokratik eğitim kavramı kadar bu eğitimin yöntem, araç ve kurumları da önemlidir. O halde demokratik eğitimle ne kastedilmektedir? Bu soruya eğitimin iki boyutunu analiz ederek cevap bulabiliriz. Birincisi tüm dünyada aynı şekilde geçerli olan temel bilimlerin çocuğa öğretilmesidir ki; fizik, kimya, biyoloji, matematik, coğrafya ve benzeri bilimlerdir. İkincisi ise daha yerel, kültürel, milli ve mânevî değerlerdir ki; milletler kimliklerinin genetik kodlarını gelen nesillere bu yolla aktarırlar ve onunla pâyidar olurlar.

Eğitimin tabiî bilimler boyutu asla bir kıtaya, bir bölgeye veya millete inhisar ettirilemez. Onda tüm insanlığın katkıs1 vardır. Uzaya gönderilen bir uyduda sürtünmeyi asgariye indirme fikri kadar, tekeri icat edenin de payı vardır, bu pay küçümsenemez ve asla yok sayılamaz. Bilgi insanlığın ortak malıdır ama bunun bir Batıcı ideolojiye alet edilmemesi gerekir (Bolay, 1996: 428). Batılı ülkeler insanlığın ortak aklı denilebilecek telâhuk-u efkârla günümüze kadar katlanarak gelen bilimin sahibinin yalnızca kendileri olduğunu iddia edemezler. Bu iddia hem gerçek dışıdır, hem diğer millet ve medeniyetleri yok saymadır, hem de bir medeniyet intihalidir.

Eğitimin ikinci boyutunu teşkil eden yerel, kültürel değer ve renkler ise milletlerin var olma teminatı ve beka garantisidir. Gelişmiş milletlerin kültürel değerleri, örf ve ananeleri eğitimin birinci boyutu gibi evrensel değil, yereldir ve o toplumla sınırlıdır. Gelişmişlikleri gerekçe gösterilerek "çağdaş" veya "modern” oldukları iddiasıyla model alınamaz, taklit edilemez ve üst bir değer olarak sunulamazlar. Eğitimin demokratikleştirilmesi ile kastedilen şey, toplumun değerlerine bağlılık, toplumun taleplerine duyarlılık, bireyin yeteneklerine sayg1, evrensel olan bilim ve teknolojinin uluslararası standartta öğrencilere öğretilmesi ve eğitimin bir propaganda aracı olarak kullanılmasına firsat verilmemesidir.

Bunun için eğitim politikalarından, eğitim kurumlarına, öğretmen eğitiminden eğitim müfredatına kadar sistemin bir bütünlük içerisinde toplum taleplerine göre yeniden yapılandırılması gerekir. Sistem bütünlüğü ile kastedilen şey, okul yönetiminden Eğitim Bakanlığına, eğitim mevzuatından anayasaya kadar tüm süreçlerde toplum sözleşmesinin yani halkın mutabakatının esas alınmasıdır.

\section{Değerler Eğitimi}

Değerleri duyuşsal alan içerisinde yer alan, düşünce ve eylemlerimizi etkileyen, onlara yön veren zihinsel olgular olarak tanımlayabiliriz (Demircioğlu ve Tokdemir, 2008: 71). Toplumların yüzyıllar içinde oluşturduğu, 
örfe, geleneğe ve ananeye dönüştürerek atadan ahfada miras bıraktığı değerler o toplumların beka garantisi olup yaşatılması, paylaşılması ve gelen nesillere öğretilmesi gerekir. Değerlerin en büyük özelliği toplumun büyük çoğunluğu tarafından özümsenmiş ve benimsenmiş olmasıdır (Bolay, 1996: 425, Tarhan, 2012: 20).

Ancak değer kavramı ile neyin kastedildiği hususunda herkes hemfikir değildir. Tanzimat'tan beri muasır medeniyet, çağdaşlaşmak ve modernleşmek gibi kavramlarla hep Batılı değerlerin kastedildiği bilinmekte, "evrensel değer" kavramıyla da yine aynı değerlere atıf yapılmaktadır. Ancak Batılı değerlerin kilise baskısına karşı oluştuğu dikkate alınırsa bizim değerlerimizle örtüştüğü söylenemez. Toplumda da Batılılaşma talebinden söz edilemez. Osmanlı Devleti'nin zayıf düşmesi, buna karşılık Avrupa'nın güçlenmeye başlamasıyla aydınlar arasında Batılı kurum ve değerleri iktibasa yönelik eğilimler ortaya çıkmış ve Batılılaşmanın teknik bir iktibas mı, yoksa bir medeniyet alanından diğerine geçmek mi, diğer bir ifade ile Doğu medeniyetini terk ederek, Batı medeniyetini olduğu gibi kabul etmek mi olduğu (Tunaya, 2004: 18) tartışılmaya başlanmıştır.

Bu tartışmaya Avrupa'dan katılanlar da vardır. Avusturya Başbakanı Prens Metternich “Avrupa medeniyetinin farklı olduğu, doğunun örf ve âdetlerine taban tabana zıt olduğu bu sebeple Batılı değerlerin alınmasının hata olacağı" (Meriç, 1997: 165) yolundaki tavsiyelerine karşı içeriden bazıları da "Doğu medeniyeti alanından bir an evvel Batı medeniyeti alanına geçmeliyiz, Batı bir zihniyettir, bir ruhtur, bir kafadır. Bu şekilde alınmasa sadece şuursuz bir taklitten ibaret kalır. Batı çağdaş medeniyettir. Doğu ise karanlıktır" (Tunaya, 2004: 130) şeklinde karşı iddialarda bulunmaktadır. Benzer görüşü paylaşan ve hatta daha ileri giden Ağaoğlu (1972: 11-13) ise Batı medeniyetinin bölünmez bir bütün olduğunu, binaenaleyh varlığımızı devam ettirmek için onu bütünüyle benimsememiz gerektiğinde 1 srar eder.

Değerler eğitimi sadece ülkemizde değil tüm dünyada, özellikle de Batılı ülkelerde öne çıkan bir konudur. Hatta ülkemizde değerler eğitiminin gündeme gelişini, çok şeylerde olduğu gibi Batılı ülkelerdeki tartışmaların bir yansıması olarak görmek mübalağa olmayacaktır. Esefle ifade etmek gerekir ki ülkemiz etkilenen ve takip edici olma konumundan henüz çıkmış değildir.

Konuyu özetleyen ve anonim olmuş bir eğitim tavsiyesini burada hatırlamak isabetli olacaktır. Hitler Almanya'sında Nazi toplama kamplarının şahidi olmuş bir okul müdürünün öğretmenler için yayınladığı mesajdaki şu ifadeler, ahlâki olarak içi doldurulmamış bir eğitimin tehlikelerine dikkat çekmektedir. "Bir toplama kampından sağ kurtulanlardan biriyim. Gözlerim hiçbir insanın görmemesi gereken şeyleri gördü. İyi eğitilmiş ve yetiştirilmiş mühendislerin inşa ettiği gaz odaları, iyi yetiştirilmiş doktorların zehirlediği çocuklar, işini iyi bilen hemşirelerin vurduğu iğnelerle ölen bebekler, lise ve üniversite mezunlarının vurup yaktığı insanlar. Eğitimden bu nedenle kuşku duyuyorum. Sizlerden isteğim şudur: Öğrencilerinizin insan olması için çaba harcayın. Çabalarınız bilgili canavarlar ve becerikli psikopatlar üretmesin. Okuma yazma, matematik, çocuklarınızın daha fazla insan olmasına yardımcı olursa ancak o zaman önem taşır."

Batılı ülkelerde değerler eğitimini gündeme taşıyan en önemli husus, Batı medeniyetinin felsefi değerlerindeki materyalist anlayış ve mânevî değerlerdeki ihmalinden kaynaklanmaktadır. Zira Batı medeniyeti hakka değil kuvvete dayanır. Hedefine menfaati koyar. Hayatı, güçlülerin yaşama hakkına sahip olduğu, fakat zayıfların elendiği, doğal seleksiyona uğradığı bir savaş olarak görür. Bu anlayış aynı zamanda hayatta kalanın üstün ırk olduğu duygusunu beslediği için diğer toplumları köleleştirme, asimile etme veya tehcir gibi insan haysiyet ve onurunu yok eden bir bakış açısına dönüşür. Birey için nefsi arzuları tatmin esas olduğu için hedonist, zevkçi fakat diğergâm olmayan, bencil insan tipini yaygınlaştırır. Batıda kökleşen bu anlayış toplumu çözülmeye götürmekte, aileyi dağıtmakta, fertleri alkolizme, madde bağımlılığına iterek yalnızlaştırmaktadır. İşte Batı'da "değerler eğitimi” ihtiyacını doğuran saik budur.

Türkiye'de ise bütünüyle Batı bir referans kaynağı olarak kabul edildiği için değerler eğitimi de tabiri caizse bir moda gibi hüsnü kabul görmektedir. Tıpkı bir dönem okullarda şekilci bir tortu bırakıp giden "Toplam Kalite Yönetimi" salgını gibi şimdi de değerler eğitimi istilası yaşanmaktadır. Değerlerin medeniyet inşa eden sağlam düsturları göz ardı edilerek bazen hümanist perspektifler, bazen çevreci hassasiyetler, ideolojik tanımlamalar, bazen de günübirlik ahlâki kaygılarla sinırlandırılabilmektedir. Mânevî değerlerden arındırılmış ve çağdaş, evrensel değer gibi kavramlarla parlatılmış olan modernizm beyindeki ödül-ceza sistemini bozmaktadır. Hedonizmi, zevkçiliği birinci plâna çıkarmakta, bunun sonucunda egoizm ortaya çıkmaktadır. Kaliforniya sendromu olarak tanımlanan egoizm; zevke düşkünlük, hedonizm, egosantrizim (benmerkezcilik), kendi rahatını, konforunu düşünme, yalnızlaşma ve bunun sonucunda da mutsuzluk ve depresyona girme şeklinde bir çöküşle sonlanmaktadır (Tarhan, 2010: 244). 
Bolay (1996: 426) da aynı konuda eğitimimizin geçen asrın sonrasından beri pozitivist anlayışın tesiri ile metafizik fobisine girdiğini, tek yanlı, tek kanatlı, insanın mânevî yönünü ihmal ve inkâr eden bir eğitim anlayışına bel bağladığını belirtir.

O halde değerler eğitimi ile neyin kastedildiği üzerinde de bir mutabakat ihtiyacının olduğunu belirtmek mecburiyeti vardır. Aksi takdirde "cümlenin maksudu bir ama rivayet muhtelif” sözünün tersi bir tanımlama ile “cümlenin beyanı bir ama maksat muhtelif” olan çeşit çeşit değerler eğitimi tanımları ile karşılaşmış olacağız. Kavram tanımlamalarındaki zorlukları göz ardı etmeden şunları söylemek mümkündür. Değerlerin tanımlanmasında öncelikle millî aidiyetler daha sonra da milletlerarası mutabakatlar nazara alınabilir. Devletler ait oldukları inanç ve kültür havzalarının müşterekleri üzerinden değer üretebilir ve insanlığa bir medeniyet çağırısı yapabilir. Küresel ölçekte ise değerler üzerindeki mutabakat daha zor olacağından negatif alanın daraltılmasına öncelik verilmesi, yani ırk ve inanç düşmanlıklarını engelleyecek tedbirlerin alınması ve eğitimde düşmanlığa kapı açan tutumlara yer verilmemesi gerekir.

Son olarak ülkemizin kanun ve diğer yasal mevzuatında değerler eğitiminin nasıl düzenlenmiş olduğuna göz atmak faydalı olacaktır. Kanun önünde eşitlik kuralı yasama, yürütme ve yargıya yöneliktir. Böyle bir genellemeden kaçınılırsa kural etkisini, somutluğunu yitirir. Kaldı ki "Anayasanın bağlayıcılı̆̆ı” yasama, yürütme ve yargı organları arasında ayrıma yer vermemektedir. "Muayyen bir şahıs, bir zümre, bir sınıf lehine veya aleyhine kanun yapılamaz." Yasanın genel (gayrı şahsi) olması ile "eşitlik" kavramı arasındaki ilgi, bu açıdan incelenebilir (Erdem, 1981: 486-497).

1739 sayılı Millî Eğitim Temel Kanunu'nun 2. Maddesinde Milli Eğitimin amacı şu şekilde ifade edilmiştir. "Türk Milletinin bütün fertlerini, Atatürk inkılâp ve ilkelerine ve Anayasada ifadesini bulan Atatürk milliyetçiliğine bağlı; ailesini, vatanını, milletini seven ve daima yüceltmeye çalışan, insan haklarına ve Anayasanın başlangıcındaki temel ilkelere dayanan demokratik, laik ve sosyal bir hukuk Devleti olan Türkiye Cumhuriyetine karşı görev ve sorumluluklarını bilen ve bunları davranış haline getirmiş yurttaşlar olarak yetiştirmektir." (RG. 1973: say1, 14574).

Okul öncesinden, ilk ve orta öğretime kadar örgün ve yaygın eğitimin her birisinin amaçlarına tek tek bakıldığında aynı "genel amaç ve temel ilkelerin” tekrarlandığı görülmektedir. Keza 2547 sayılı Yükseköğretim Kanunu'nun 4. Maddesinde yükseköğretimin amac1; “Öğrencileri Atatürk inkılâpları ve ilkeleri doğrultusunda Atatürk milliyetçiliğine bağlı olarak yetiştirmek” şeklinde belirlenmiştir. Yükseköğretimin plân ve programlarının nasıl düzenleneceğini belirleyen 5. maddedeki ana ilkelerde ise "Öğrencilere, Atatürk inkılâpları ve ilkeleri doğrultusunda Atatürk milliyetçiliğine bağlı hizmet bilincinin kazandırılmasının sağlanacağı" ifade edilmektedir (RG. 1981: say1, 17506).

\section{Sonuç}

Duygu ve yeteneklerine had konulmayan insanlar için eğitim, kendini gerçekleştirme yani âzamî gelişim noktasına ulaşmanın en vazgeçilmez aracı ve çok temel bir insan hakkıdır. İnsanlar gelişim basamaklarını ilim öğrenerek çıkabilirler. Ancak eğitimin muhtevasının nasıl belirleneceği, bireyin yeteneklerini inkişaf ettirmek için mi, yoksa insanları bir amaca uygun olarak şekillendirmek ve adeta formatlamak için mi kullanılacağı hususunda tartışmalar devam etmektedir.

Eğitimin bir yetenek geliştirme aracı olması, değerlerin demokratik bir şekilde toplum taleplerine uygun olarak belirlenmesi, bilimin evrensel olan kısmının rekabetçi bir anlayışla müfredatta yerini alması, ayrıca inanç, örf, anane ve kültür gibi aidiyetlerin korunması elbette arzu edilen hususlardır. Fakat eğitimin antidemokratik yollarla, dikte edici tavırlarla, toplumu devre dışı bırakarak, bazı ideolojilerin taşıyıcısı olacak şekilde bir kimlik dönüştürme aracı olarak kullanılması kesinlikle kabul edilemez.

Zemin etüdü yapmadan bina yapmak ne kadar risklere açıksa, eğitimi demokratikleştirmeden eğitim için değer arayışları yapmak da yönlendirmelere o kadar açıktır. Önceliği eğitimin demokratikleştirilmesine vermek, hem eğitimde gelecek arayışlarındaki belirsizliği ortadan kaldıracak, hem de eğitime ruh verecek değerlerin veya değerler eğitiminin yol haritasını daha anlaşılır hale getirecektir. 


\section{References}

Açıkgenç, A. (2009). Küreselleşme Karşısında Yeni Bir Eğitim Felsefesine Doğru [Towards a New Education Philosophy Against Globalization], H. R. Açar (Editör), Küreselleşme Sürecinde Eğitim Sorunlarının Felsefi Boyutu [Philosophical dimension of Education Problems in Globalization Process] (s. 79-97) içinde, Uluslararası Eğitim Felsefesi Kongresi, Eğitim Bir-Sen Yayınları, Ankara.

Ağaoğlu, A. (1972). Ü̧̧ Medeniyet, [Three Civilization] Başbakanlık Kültür Müsteşarlığı Kültür Yayınları, İstanbul, Milli Eğitim Basımevi.

Altan M. Z. (1999). Çoklu Zekâ Kuramı, [Multiple Intelligene Theory] Kuram ve Uygulamada Eğitim Yönetimi Dergisi, Sayı:17, s. 105-117.

Aydın, M. (2009). Küreselleşme Sürecinde Eğitim Sorunlarının Felsefi Boyutu [Philosophical dimension of education problems in globalization process], H.R. Açar (Editör), Uluslararası Eğitim Felsefesi Kongresi (ss. 32-36) içinde, Eğitim Bir-Sen Yayınları, Ankara.

Baltacı, C. (1996). Osmanlı Eğitim Sistemi, [Ottoman Educational System] Ankara, Yeni Türkiye, Yı1 2, Sayı 7. s. 467-470.

Bolay, S. H. (1996). Eğitimimizin Felsefi Temelleri, [Philosphical Foundations of Our Education] Ankara, Yeni Türkiye, Y11 2, Sayı 7. s. 422-429.

Bursalığlu, Z. (1991). Okul Yönetiminde Yeni Yapı ve Davranış, [New Structure and Behavior in School Management] Ankara, PEGEM Yayın No 2.

Demircioğlu, İ. H. ve Tokdemir, M. A. (2008). Değerlerin Oluşturulma Sürecinde Tarih Eğitimi [History Education in the Process of Creating Values], Değerler Eğitimi Dergisi, Cilt 6, No. 15, s. 69-88.

Erdem, F. (1981). Adalet Önünde Eşitlik, [Equality Before Justice] Yargıtay Dergisi, s. 486.

Ergin, O. N. (1977). Türkiye Maarif Tarihi, [Turkey's Educational History] Cilt 3-4, İstanbul, Eser Matbaası.

Ertürk, S. (1972). Eğitimde Program Geliştirme, [Curriculum Development in Education] Ankara, Yelkentepe Yayınları.

Gökalp, Z. (1994). Türkçülüğün Esasları [The Principles of Turkism], İstanbul, İnkılâp Kitabevi.

Gür, B. S. (2006). Öğrenci Merkezli Eğitimin Çıkmazları [The Dilemmas of Student-Centered Education], Eskişehir, Eski Yeni Dergisi, s.34-45.

Kant, I. (1900). Kant On Education (Ueber Padagogik), Translated by A. Churton, Boston, U.S.A. D. C. Heath ,\& Co., Publishers.

Meriç, C. (1997). Bu Ülke [This County], İstanbul, İletişim Yayınları.

Şimşek, A. (2000). Sınıfta Demokrasi [Democracy in the Classroom], A. Şimşek (Editör), Özgürlükçü Öğrenme (ss.26-52) içinde, Ankara: Eğitim-Sen Yayınları.

Tarhan, N. (2010). Psiko-sosyal Sermaye Olarak Değerler: Zenginleşiyor muyuz? [Values as Psychosocial Capital: Are We Being Rich?] Değerler Eğitimi (ss. 242-248) içinde, İstanbul, İl Milli Eğitim Müdürlüğü.

Tarhan, N. (2012). Güzel İnsan Modeli, [Model of Good People] 4. Baskı, İstanbul, TİMAŞ Yayınları.

Tezcan, M. (1985). Eğitim Sosyolojisi, [Sociology of Education] 4. Bask1, Ankara Üniversitesi Eğitim Bilimleri Fakültesi Yayınları.

Toku, N. (2009). Küreselleşme ve AB Sürecinde Türk Milli Eğitim Sistemi, [Turkish National Education System in Globalization and EU Process] H.R. Açar (Editör), Küreselleşme Sürecinde Eğitim Sorunlarının Felsefi Boyutu [Philosophical Dimension of Education Problems in Globalization Process] (ss. 240-245) içinde, Uluslararası Eğitim Felsefesi Kongresi, Ankara, Eğitim Bir-Sen Yayınları.

Tunaya, T. Z. (2004). Türkiye'nin Siyasi Hayatında Batıllaş̧ma Hareketleri [Westernization Movements in Turkey's Political Life], İstanbul: Bilgi Üniversitesi Yayınları, s. 68. 
Eğitime Biçilen Rol: Yetenek Geliştirme Mi? Kimlik Dönüştürme Mi?

Türkiye Cumhuriyeti Anayasası [Constitution of the Republic of Turkey], Kanun No: 2709 Kabul Tarihi: 7.11.1982.

Yükseköğretim Kanunu [Higher Education Law], Kanun No: 2547, R. Gazete: Tarih ve sayı: 06.11.1981; 17506. 